SHS Web of Conferences 23, 02002 (2016)

DOI: $10.1051 /$ shsconf/ 20162302002

C) Owned by the authors, published by EDP Sciences, 2016

\title{
ZAKAT FOR THE ORPHANS IN THE DEEP SOUTH OF THAILAND
}

\author{
Mrs. Kanlaya Daraha \\ Faculty of Humanities and Social Sciences \\ Prince of Songkla University \\ d_kallaya@yahoo.com
}

\section{INTRODUCTION}

In the past nine years, the violence situation has spiked in the Deep South Pattani, Yala, and Narathiwat provinces see Figure 1 and parts Songkla province Nathawi, Sabayoi, Chana, and Thepa districts see Figure 1 . The population of Narathiwat, Pattani and Yala provinces is approximately 1.8 million, of whom about 80 per cent are Malay Muslims. Many speak the Patani Malay dialect, known in Thai as Yawi.

Since January 2004, the violence situation occurred these provinces ; more than 3,000 people have died and more than 5,000 have been injured. Jagan, 2008.

There are some violence situation in the Deep South during nine years: bombing, burning and damaging schools, killing teachers and shooting the school bus, which affected the mental health of children who have witness the brutal starting of the people in the community; some children lost their parents and some children are injured; some of them are afraid to go to school and go outside to play and dare not create relations with anybody Hope Learn Pattani, 2011 . 


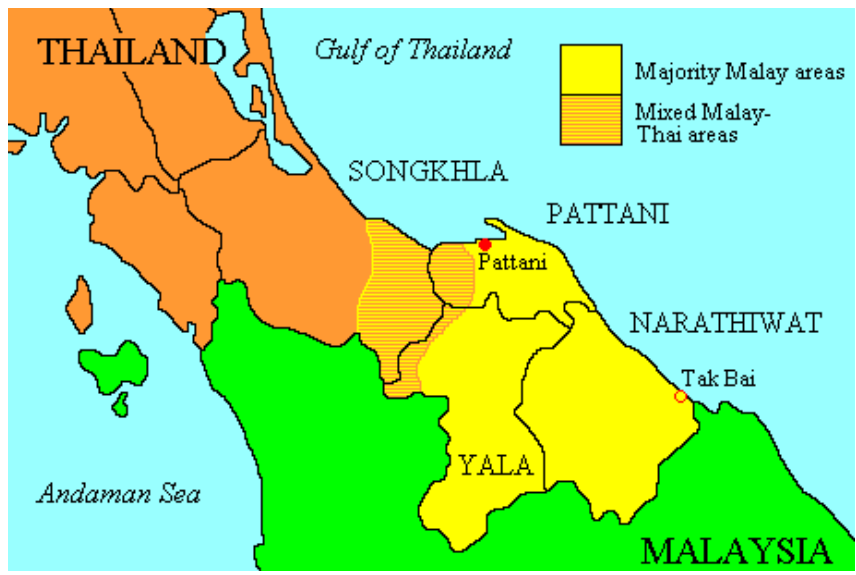

Figure 1. The Map of Violence Situation

\section{EDUCATION UNDER ATTACK IN THE SOUTHERN MOST OF THAILAND}

There are hundred of schools and more than 300 schools were burnt in the provinces have been severe damaged or destroyed over the past six years and many students now to go to school and attend school under armed guard. Due to unrest education authorities have been forced to repeatedly closed schools for many periods from days to month Hope Learn Pattani, 2011 .

The Southern Teachers' Federation reported that 117 teachers had been killed by end of July 2009 and according to Ministry of Education MoE indicated the number of arsons attacked against school rising up 43 in 2006 to 164 in 2007, then fell to just ten in 2008 during a lull in the conflict and furthermore, the MoE also reported that 14 schools were burnt down in Narathiwat and Pattani in 2008 .

The victim in attacks were including the members of guards, school janitors, school bus drivers and school builders as well as teachers and students. There were four reported -cases of teachers being shot in front of students, two of them were shot in front of the students aged 9 to 11; four cases of teachers being shot or blown up in front of other colleagues; and one case of a teacher was in the car. Most of teachers killed were assassinated individually, many of them by motorbike pillion passenger assassins following to work or home and many others while riding to or from work Hope Learn Pattani, 2011. 
Some schools are being close early to avoid the need for teachers to travel late in the day and early evening. That affects on students education because they can not receive the opportunity for an education that they should be Hope Learn Pattani, 2011 .

Students and teachers, and schools have been caught in the conflict in the Deep South. Separatist insurgents have killed and threatened teachers, including both Thai Buddhists and Malay Muslims; bombs and burned government schools and the Government tried to the access to a quality education to hundreds of thousands students in the Deep South Deep South Watch, 2010 .

The Center of Mental Health 15 and the violence related Mental Health Surveillance: VMS in the Deep South of Thailand found that from October 2011 to March 2012, in all areas in the Deep South 331 children aged 0-15 affected the mental health: were classified as Narathiwat 177, Yala 130, Pattani 23 and in Songkhla 1; and Ministry of Social Development and Human Security found the orphans affected the violence situation since 2004, 4,815 children Department of Mental Health Center, District ,2012 .

The government has the policy for rehabilitating the people affected the violence situation and in 2012, the government supports the Southern Border Province Administrative Center for rehabilitating them 2,080 baht (Prime Minister Secretariat, 2012 .

\section{MAINSTREAM EDUCATION INSUFFICIENT NUMBER OF TEACHERS AND EDUCATION EQUIPMENT}

Due to continued the violence situation occurs drastically and the schools were burnt, they affected on students' education because hundreds of teachers asked for transfer and had to move out of the Deep South. It caused shortage of qualified teachers. If we compare them with the religious schools, the government schools are better- equipped with education materials but in the rural areas are still insufficiency and however, some schools are materially well-equipped but both students and teachers are not aware or how to use them. Many things are broken and there are no funds to repair Hope Learn Pattani, 2011. 


\section{THE VIOLENT SITUATION IMPACTS ON CHILDREN}

The violent situation occurred since 2004, it affected on students on mental health seriously. Tohmeena Pechdao , a physician attached to Mental Health Center 15 viewed that :

The traumatic impacts of the incidents had become deeply rooted in the children's minds and might take five to 10 years to heal" and furthermore, she indicated that :

One of the traumatic cases we found the shooting of the teacher in front of 40 students in Narathiwat over a year ago. After conducting group therapy with the children, we found that some of them had nightmares and,even in their sleep, had hidden under the bed as if to hide from the bullets".

She cited ,it had another case of a four -year girl who was his mother when four gunmen passed into their house to search for a hidden weapon. One of them pointed the gun at her mother's head until the girl screamed and insisted they knew nothing about any weapon. The gunmen gave up and left the house Bangkok Post, 2007 and she viewed :

Ever since, the girl has become panic-stricken on hearing the sound of a motorcycle at night and can not sleep

For remedy, it had a plan to produce handbooks about caring for traumatized children. There were two kinds, one for public health workers in the area and another for parents, teachers and people close to the children. Teachers could play the big role in helping traumatized students, but they need healing too Bangkok Post, 2007 .

The Ministry of Public Health establishes the first Child Traumatic Stress in Yala to take care of Children affected on violent situation. They have suffered more mental health problems than children experiences natural disasters Foreign Office, the Government Public Relations Department, Office of the Prime Minister, 2008 .

\section{ZAKAT OBLIGATORY CHARITY}

One of the most important principles of Islam is that all things belong to God, and the word Zakat means Purification" and Growth Zakat of Islams an obligatory duty and one of the 
five pillars of Islam. It is mandatory when two conditions are simultaneously satisfied which are ... Nisab and the Due Date.

The category of people is defined in surah at-Taubah 9 verse 60: This is the Islam Welfare. The aims are only for the poor and needy , and those who collect them, and those whose hearts are be reconciled, and to free the captives and debtors, and for the cause of Allah, and for the wayfarer; a duty imposed by Allah. Allah is knower, Wise.” The Holy Qur'an 9:60 .

Each Muslim has duty to pay zakat individually, that is voluntary charity" and the Prophet said Charity is a necessity for every Muslim then the orphans, every Muslim must realize to get them the charity.

\section{RESEARCH OBJECTIVE}

The objectives of this study is:

To investigate the communities and stakeholders in handing on zakat for the orphans affected by the violent situation in the Deep South, Thailand and the path of remedying after the violence.

\section{METHODOLOGY}

The research is done through qualitative approaches to collect data: through extensive interviews, casual conversation, formal and informal observations. There are in-depth portraits of two students, 15 parents, five religion leaders, and three civil society informants from four districts: Tak Bai district in Narathiwat province, Nongchick and Muang districts in Pattani province, and Muang district in Yala province. Those situations are frequently ocurring the violence dramatically would however provide and support much fuller access to their views across arrange of the issues of problem. A total of semi-structure interviews with open-ended questions were conducted for the purpose of study in 2009. All interviewers were audio tape-recorded and informal conservations. In this study, the data were gathered to learn of each case. After that, the data obtained from this case were analyzed. 


\section{RESULT}

The students viewed that the violence situation affected on their education and their mental health. Most of them dropped out of school, because lone mothers became the head of the family and had to be responsible for all household burden. The government and the organization had not yet covered their support to child development. They need the army guard in the Deep South and the government should give the scholarship to the the students and zakat until they finish Bachelor Degree.

The parents viewed that they needed the violence stopped. The government and the organizations had to rehabilitate and provide the students who affected by the violence in education and relief their mind. The government must construct the reconciliation, the security and the harmony in the Deep South and provide the scholarships for children in the Deep South.

The religion leader proposed the government to construct the harmony and reconciliation in the Deep South because it affected on students in education and their mental health and on their duties ,they handed on zakat for the students and the orphans who affected by the violence situation simultaneously.

The civil society viewed that Muslim Association proposed the justice in the Deep South and visited the students, the orphans and the people affected by the violence situation, and it had Zakat to provide the scholarship for the students and the orphans in primary school, secondary school and Bachelor Degree. The people trusted them because they have service minded and the best policy to empower them.

Some of the communities and the stakeholders viewed:

We need zakat for the orphans for giving them in education and it can also help their mothers to take care their children because they only earn money for their family The religion committee in Masjid Pattani . 
Every year, we donate and give zakat for the orphans in Pattani because of the violent situation occurring since 2004. Faculty of Humanities and Social Sciences collects and gives them for education and new clothes for wearing in Hari Raya" The Huso Islam committee .

Zakat for the orphans, the Charity, we do, we can get the merit. We give the opportunity for them on education and conduct wellbeing for the orphans. We should give for the vulnerable groups. This is the good attitude to help another people and it make us happy and they are also happy and society is very well The senior student .

Zakat is the equity for people and it gives the opportunity for the vulnerable groups. It constructs the best way, the responsibility together to look after each other. It is sacrificial and the Charity for the orphans and society" The civil society .

\section{RECOMMENDATIONS}

There are some recommendations:

(1) The government must stop the violence situation and construct the reconciliation;

(2) It should have the scholarship for students, specifically Muslim youth;

(3) The community must construct the surveillance in their community;

(4) It must have Health Care Center for the students and the orphans who affected by the violence

(5) The roles of family and family members must be strengthened;

(6) It should construct the activities, i.e., sports or music for rehabilitating the orphans;

(7) It must have the human capital and teach the religion for conducting the students and the orphans to be good citizen";

(8) It must respect the human rights for every target groups;

(9) It should have media language for people because most of them are unable to speak and write Thai language.

(10)Zakat must be provided for the orphans those affected by the violent situation.

(11) The Government must construct the security sustainable in the Deep South. 


\section{REFERENCES}

Bangkok Post. 2007. Boy Who Saw Dad Blown up Embodies Kid's Woes in South. Retrieved December 30, 2012 http://teakdoor.com/thailand-and-asia-news/11223-threecharged-with-south-bombings.html

Deep South Watch. 2010. Thailand Education Under Attack in South. Retrieved December 25, 2010 http://www.deedsouthwatch.org/node/956

Department of Mental Health Center, District . 2012. Executive Summary 8 Years of Administrative Rehabilitation Have Been the Psychological Impact on Violent Situation in the Deep.

Department of Mental Health Center, District ，(2012). Executive Summary 8 years of Administrative Rehabilitation have been the psychological impact on the violent situation in the Deep South. Ministry of Public Health.

Foreign Office, the Government Public Relations Department, Office of the Prime Minister. 2008. Mental Rehabilitation for Children Affected by Unrest in the South.

Hidayah Foundation.2003. Who is entitled to receive Zakat. Retrieved February 20,2013 Hope Learn Pattani. 2010. Education Under Attack in the Southernmost of Thailand.

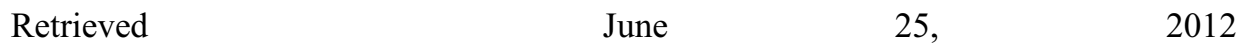
http://www.facebook.com/note.php?note $\mathrm{id}=215698968479956$

Jagan, L. 2008. Violence Worsens in Thailand. Retrieved June 25, 2012 http://www.the national.ae/news/world/asia- pacific/violence-worsens-in-thailand

Prime Minister Secretariat. 2012. Government House. His Approval Rules and Procedures to Help Heal and Restore the Damage Has Been Affected by the Unrest in the Southern Provinces. And Approve the Budget for Fiscal Year.

The Secretariat of the Cabinet. 2012. Government House in Bangkok. The Approval Criteria and Procedures to Help Heal and Restore Those That Have Been Damaged by the Impact of the Unrest in the Southern Provinces. And Approved Budget Fiscal 2012 Reported Reserves to Pay for Emergency or Necessary. 